\title{
PENGARUH KETERAMPILAN MENGAJAR DAN KEDISIPLINAN GURU DALAM PROSES BELAJAR MENGAJAR
}

\author{
M. Saipul Watoni \& Lalu A. Hery Qusyairi \\ STIT Palapa Nusantara Lombok NTB \\ heryqusyairi@gmail.com
}

\begin{abstract}
This research is entitled "The Influence of Teaching Skills and Teacher Discipline in the Teaching and Learning Process on Student Achievement in Social Studies Subjects for the 2020/2021 Academic Year". The aim of this research is to find out how much influence teaching skills and teacher discipline in the teaching and learning process (PBM) have on student achievement in social studies subjects. The approach used in this research is a quantitative approach with the type of survey research. The population used as subjects in this study were all Social Studies students of class VIII consisting of three classes at MTs NW Selebung for the academic year 2020/2021. In this study, the technique used in sampling is a random sampling technique with the class as the sample unit so that all students are studied randomly by providing equal opportunities to all members of the population, the minimum sample size is 50.98 so 51 students will be taken from class VIII MTs NW Selebung. The main data collection technique in this research is to use a closed questionnaire given to all students who are the research sample, there are two types of questionnaires used in collecting data in this study, namely a questionnaire about teaching skills and teacher discipline which will be filled out by students. For data analysis techniques used Pearson product moment analysis techniques, t-test (t-test) and multiple correlation. Based on the results of the calculations obtained coefficient $t$ count of 5.75 with a contribution of $31.58 \%$ for teacher teaching skills, $t$ count of 4.42 with a contribution of $23.43 \%$ for teacher discipline, $t$ count of 9.33 with a contribution of $27.98 \%$ for teaching skills and teacher discipline, with a significance level of $5 \%$, dk $=51$ obtained $t$ table of 4.08 means that $t$ count $t$ table, thus there is a significant influence on teacher teaching skills, teacher discipline as well as teaching skills and teacher discipline together in the teaching and learning process in social studies subjects at MTs NW Selebung for the academic year 2020/2021.
\end{abstract}

Keywords : Skills, Discipline

\begin{abstract}
Abstrak : Penelitian ini berjudul "Pengaruh Keterampilan Mengajar Dan Kedisiplinan Guru Dalam Proses Belajar Mengajar Terhadap Prestasi Belajar Siswa Pada Mata Pelajaran IPS Tahun Pembelajaran 2020/2021”. Tujuan yang ingin dicapai dalam penelitian ini adalah untuk mengetahui seberapa besar pengaruh keterampilan mengajar dan kedisiplinan guru dalam proses belajar mengajar (PBM) terhadap prestasi belajar siswa pada mata pelajaran IPS.
\end{abstract}

AS-SABIQUN : Jurnal Pendidikan Islam Anak Usia Dini

Volume 3, Nomor 1, Maret 2021; 113-126

https://ejournal.stitpn.ac.id/index.php/assabiqun 
Pendekatan yang digunakan dalam penelitian ini adalah pendekatan kuantitatif dengan jenis penelitian survei. populasi yang dijadikan subjek dalam penelitian ini adalah seluruh siswa IPS kelas VIII yang terdiri dari tiga kelas di MTs NW Selebung tahun pelajaran 2020/2021. Dalam penelitian ini teknik yang digunakan dalam pengambilan sampel adalah teknik random sampling dengan kelas sebagai unit sampel sehingga yang ditelitai seluruh siswa yang dilakukan secara acak dengan memberikan kesempatan yang sama kepada semua anggota populasi, jumlah sampel minimalnya adalah 50,98 maka akan diambil sebanyak 51 siswa dari kelas VIII MTs NW Selebung. Teknik pengumpulan data utama dalam penelitian ini adalah dengan menggunakan angket tertutup yang diberikan kepada seluruh siswa yang menjadi sampel penelitian, terdapat dua jenis angket yang digunakan dalam pengumpulan data penelitian ini yaitu angket tentang keterampilan mengajar dan kedisiplinan guru yang nantinya diisi oleh siswa. Untuk teknik analisis data digunakan teknik analisis pearson product moment, uji-t (t-tes) dan korelasi ganda, Berdasarkan hasil perhitungan diperoleh koofisien t hitung sebesar 5,75 dengan kotribusi sebesar $31,58 \%$ untuk keterampilan mengajar guru, t hitung sebesar 4,42 dengan kontribusi sebesar 23,43\% untuk kedisiplinan guru, t hitung sebesar 9,33 dengan kontribusi sebesar 27,98\% untuk keterampilan mengajar dan kedisiplinan guru, dengan taraf signifikansi $5 \%, \mathrm{dk}=51$ diperoleh $\mathrm{t}$ tabel sebesar 4,08 ini berarti bahwa $\mathrm{t}$ hitung $\geq \mathrm{t}$ tabel, dengan demikian terdapat pengaruh yang signifikan keterampilan mengajar guru, kedisiplinan guru maupun keterampilan mengajar dan kedisiplinan guru secara bersama-sama dalam proses belajar mengajar pada mata pelajaran IPS di MTs NW Selebung tahun pelajaran 2020/2021.

Kata Kunci : Keterampilan, Kedisiplinan

\section{PENDAHULUAN}

Pendidikan merupakan hal yang sangat penting karena itu merupakan kebutuhan manusia yang esensial, pendidikan dapat mengembangkan potensi yang ada pada diri manusia, baik potensi jasmani maupun rohani, tujuan umum pendidikan harus diarahkan untuk mencapai pertumbuhan, keseimbangan, kepribadian, manusiawi menyeluruh, melalui latihan jiwa intelek, jiwa rasional, keseimbangan, dan penghayatan lahir (Rama yulis, $2002: 69)^{1}$

\footnotetext{
${ }^{1}$ Rama yulis. 2002. Ilmu Pendidikan Islam. Jakarta : Kalam Mulia Hal : 69
} 
Sekolah merupakan sebuah lembaga pendidikan formal yang mana mempunyai pengaruh sangat besar terhadap perkembangan dan pembentukan kepribadian siswa, karena dilembaga inilah para siswa menerima pengetahuan yang bertujuan untuk mendewasakan siswa.

Guru adalah suatu profesi yang artinya suatu jabatan yang memerlukan keahlian khusus sebagai guru yang tidak dapat dilakukan oleh sembarang orang diluar bidang pendidikannya, walaupun kenyataannya masih banyak terdapat hal-hal tersebut diluar bidang kependidikan. Profesionalisme seorang guru merupakan suatu keharusan dalam mewujudkan sekolah berbasis pengetahuan yaitu pemahaman tentang belajar dan pembelajaran, kurikulum dari perkembangan manusia termasuk gaya belajar. (Kariman,2002 yang dikuti oleh hamzah, 2012:9 $)^{2}$

Didalam proses belajar mengajar guru sebagai pengajar dan siswa sebagai subjek belajar, yang mana kesemuanya dituntut adanya profil kualifikasi tertentu baik dalam hal pengetahuan, kemampuan, sikap dan tata nilai serta sifat-sifat pribadi agar proses itu dapat berlangsung dengan efektif dan efesien. Untuk itu, orang kemudian mengembangkan berbagai pengetahuan serta keterampilan, misalnya seperti psikologi pendidikan, metode mengajar, pengelolaan pengajaran dan ilmu-ilmu lain yang dapat menunjang dalam proses belajar mengajar itu.

Keberhasilan siswa dalam hal belajar dan pembelajaran akan dipengaruhi oleh beberapa faktor, salah satunya yaitu seorang guru. Yang mana peran guru begitu penting, oleh karenanya seorang guru dituntut untuk memiliki profesionalisme dan kualitas yang dapat dipertanggung jawabkan. Guru hendaknya dapat mengembangkan kemampuannya seperti keterampilan mengajar dalam proses belajar mengajar sehingga mampu meningkatkan keaktifan serta prestasi belajar siswa. Selain itu guru yang fropesional juga akan selalu mengembangkan kompetensi personal atau kepribadian , salah satu kompetensi kepribadian tersebut adalah disiplin.

Keberhasilan belajar siswa itu tidak terlepas dari keberhasilan proses belajar mengajar yang kemungkinan besar dipengaruhi oleh keterampilan mengajar dan kedisiplinan guru. Sekarang ini, guru disekolah dituntut menjadi seorang panutan yang

2 B.Uno,Hamzah.2012. Profesi Kependidikan . Jakarta : Bumi Aksara. Hal : 9 
baik bagi siswanya, atau ia harus dapat memberikan contoh yang baik ketika mengajar sebagai cerminan bagi siswa bagaimana berperilaku yang baik. Jadi ketika bertindak, siswa selalu berpatokan pada sikap atau perilaku disekolah, bisa disimpulkan bahwa keterampilan mengajar dan kedisiplinan dapat memotivasi siswa untuk belajar karena siswa biasanya akan mengikuti perilaku gurunya.

Dari permasalahan diatas penulis tertarik untuk mengadakan suatu penelitian yang tentang Pengarub Keterampilan Mengajar dan Kedisiplinan Guru Dalam Proses Belajar Mengajar (PBM) Terbadap Prestasi Belajar Siswa.

\section{METODE PENELITIAN}

\section{Jenis Penelitian}

Metode penelitian menyangkut alat dan teknik untuk melaksanakan penelitian. Hal yang demikian dapat dilihat dari pemilihan metode yang tepat untuk meneliti suatu masalah atau objek penelitian. Adanya perbedaan objek penelitian di lapangan, memungkinkan untuk menggunakan atau memilih metode yang berbeda.

Metode merupakan suatu strategi, proses, dan pendekatan dalam memilih jenis serta dimensi ruang dan waktu dari data yang diperlukan (Sudjana, 2017 : 52). Adapun metode penelitian yang dpergunakan untuk menjawab masalah penelitian ini adalah metode penelitian deskriftif dengan jenis penelitian survei ${ }^{3}$.

Metode penelitian deskriftif yaitu suatu metode penelitian yang dapat dijelaskan untuk memperoleh informasi tentang suatu gejala pada saat penelitian dilakukan. (Arief furchan dalam Suhainiyah, 2008:19).

Jenis penelitian survei merupakan penelitian dengan mengumpulkan informasi dari suatu sampel dengan menanyakan melalui angket atau interview supaya nantinya menggambarkan berbagai aspek dari populasi (fraenkel dan Wallen dalam Riyanto, 2001:22)

Karlinger (1996) dalam Riduwan (2004 : 49) mengatakan bahwa penelitian survei merupakan penelitian yang dilakukan pada jumlah populasi besar maupun kecil, tetapi data yang dipelajari adalah data dari populasi tersebut, sehingga ditemukan

\footnotetext{
${ }^{3}$ Sanjaya, Wina. 2017. Strategi Pembelajaran. Jakarta : Kencana. Hal : 52
} 
kejadian - kejadian relative, distribusi, dan hubungan antar variabel sosiologis maupun psikologis. $^{4}$

Sedangkan pendekatan yang digunakan dalam penelitian ini adalah pendekatan kuantitatif dimana bentuk penelitian ini akan menjelaskan secara wajar pengaruh keterampilan mengajar dan kedisiplinan guru terhadap prestasi belajar siswa.

\section{Populasi dan Sampel Penelitian}

Jumlah populasi dalam penelitian ini adalah :104 yang terdiri dari laki-laki 44 orang dan perempuan berjumlah 60 orang dan jumlah sampel sebanyak 51 siswa dari kelas VIII MTs NW Selebung.

\section{Jenis dan Sumber Data}

\section{Jenis Data}

Menurut Sugiono, (2013:27) jika dilihat dari wujudnya jenis data dalam penelitian pada dasarnya dikelompokkan menjadi dua yaitu:

a. Data kualitatif yaitu data yang dinyatakan dalam bentuk kata, kalimat dan gambar yang biasanya berhubungan dengan nilai misalnya baik-buruk, rajinmalas dan lain-lain.

b. Data kuantitatif yaitu nilai dari perubahan yang dinyatakan dalam bentuk angkaangka (numerical data)

Apabila diperhatikan uraian tersebut, maka dalam penelitian ini jenis data yang digunakan adalah kuantitatif. Data kuantitatif yang dimaksud adalah data tentang penilaian pengaruh keterampilan mengajar dan kedisiplinan guru dalam proses belajar mengajar terhadap prestasi belajar siswa. ${ }^{5}$

\footnotetext{
${ }^{4}$ Riduwan. 2015. Belajar Mudah Penelitian untuk guru karyawan dan peneliti pemula. Jakarta: ALFABETA. Hal : 49

${ }^{5}$ Sugiono. 2013. Metode Penelitian Administrasi. Bandung: Alvabeta. Hal :27
} 


\section{Sumber Data}

Selain pentingnya mengetahui jenis data dalam penelitian satu hal yang tidak boleh ditinggalkan adalah sumber data, karena berkaitan dengan hal yang mencakup darimana data tersebut diperoleh.

Data primer adalah data yang diperoleh langsung dari responden dengan memberikan pertanyaan yang berpedoman pada angket atau quisioner, dalam hal ini data yang diperlukan adalah data tentang keterampilan mengajar dan kedisiplinan guru dimana jumlah sampel berjumlah 51 siswa kelas VIII semester genap di MTs NW Selebung

Data sekunder adalah data yang di peroleh dari lapangan atau sekolah yang berasal dari catatan-catatan lapangan penelitian (jurnal) atau dokumen yang sudah ada, adapun data yang diperlukan adalah data tentang keadaan siswa dan hasil prestasi belajar siswa.

\section{Teknik Pengumpulan Data}

a. Variabel bebas (indefendent variabel)

Variabel bebas adalah variabel yang mempengaruhi atau penyebab. Dalam penelitian ini yang menjadi variabel bebasnya sesuai dengan judul ini ada dua yaitu : keterampilan mengajar guru $\left(X_{1}\right)$ dan kedisiplinan guru $\left(X_{2}\right)$.

b. Variabel terikat

Variabel terikat adalah ciri-ciri tertentu yang merupakan akibat pada umumnya dalam tata urutan waktu terjadinya kemudian. Pada penerapan ini sesuai dengan judul variabel terikatnya adalah prestasi belajar (Y).

\section{Instrumen dan Teknik Pengukuran}

a. Dokumentasi

Studi dokumen dalam penelitian ini merupakan suatu cara yang ditempuh untuk mengumpulkan data dengan jalan mengumpulkan segala macam dokumen baik dari tulisan-tulisan, laporan-laporan, bukti dan sebagainya yang 
dapat memberikan informasi atau keterangan peristiwa atau keadaan. Hal ini sesuai dengan apa yang diungkapkan oleh Arikunto (2006 : 251) menyatakan bahwa : "Metode dokumentasi adalah mencari data mengenai hal-hal atau variabel yang berupa catatan atau transkrip, buku, surat kabar, majalah, prasasti dan sebagainya". ${ }^{6}$

Dalam penelitian ini dokumen yang dimaksud adalah dokumen yang berbentuk catatan dalam nilai ulangan siswa, yakni yang berupa nilai-nilai siswa yang dijadikan sampel.

b. Kuisioner (angket)

Menurut Arikunto (2016 : 151) kuisioner adalah sejumlah pertanyaan tertulis yang digunakan untuk memperoleh informasi dari responden dalam arti laporan keperibadian atau hal-hal yang ia ketahui.

Menurut Sugiono ( 2013 : 86 ) menyatakan bahwa titik tolak penyusunan angket adalah variabel-variabel tersebut ditentukan indikator yang akan diukur, dari indikator ini kemudian dijabarkan menjadi butir-butir pertanyaan. ${ }^{7}$

Dengan demikian, yang dimaksud dengan kusioner (angket) adalah sejumlah pertanyaan yang sengaja dibuat oleh peneliti untuk mendapatkan informasi dari objek yang diteliti.

\section{Teknik Analisis Data}

Data yang terkumpul tidak dapat memberikan informasi hasil penelitian apabila belum dianalisa, untuk itu di dalam menganalisa data penelitian menggunakan rumus uji korelasi ganda, namun sebelum melakukan analisis data terlebih dahulu perlu dilakukan beberapa hal antara lain:

\section{Teknik Deskripsi Data}

Sebelum melakukan analisis data terlebih dahulu mencari klasifikasi data keterampilan mengajar dan kedisiplinan guru dalam proses belajar mengajar terhadap prestasi belajar siswa dengan menentukan skor maksimal ideal (SMi), harga rata-rata

\footnotetext{
${ }^{6}$ Suharsimi Arikunto.2016. Prosedur Penelitian Suatu pendidikan Praktik. Jakarta : Rineka CIPSta. Hal: 151

${ }^{7}$ Sugiono. 2013. Metode Penelitian Administrasi. Bandung: Alvabeta. Hal : 86
} 
ideal (SDi) angka-angka Mi diperoleh dengan cara, mean ideal $(\mathrm{Mi})=\frac{1}{\mathbf{2}} \times$ ( skor maksimal ideal + skor minimal ideal), dan Standar Deviasi ideal(SDi) $=1 / 6 \times$ (skor maksimal ideal - skor minimal ideal.

\section{Teknik Uji Persyaratan Analisis}

Sebelum data digunakan atau dianalisis terlebih dahulu data tersebut di uji persyaratan, uji persyaratan yang digunakan adalah uji normalitas data.

Uji normalitas data adalah dapat dilakukan dengan cara menggunakan rumus chikuadrat $\left(\mathrm{x}^{2}\right)$ rumus yang digunakan untuk menghitung atau mencari $\mathrm{x}^{2}$ yaitu:

$$
\mathrm{X}_{\text {hitung }}^{2} \sum^{\frac{(f o-f e)^{2}}{f e}} \quad \text { (Riduwan,2005:182) }
$$

Uji Linieritas regresi

Dilakukan untuk mengukur derajat keeratan hubungan, untuk data yang dihubungkan berpola linier diuji dengan linearitas regresi dengan rumus ;

$$
\mathrm{F}_{\text {hitung }}=\frac{R J K_{T C}}{R J K_{E}}
$$

\section{Teknik Uji Hipotesis}

Untuk mencari koofisien keterampilan mengajar $\left(\mathrm{X}_{1}\right)$ dan kedisiplinan guru $\left(\mathrm{X}_{2}\right)$ terhadap prestasi belajar siswa $(\mathrm{Y})$

$$
\mathrm{R}_{1} \cdot \mathrm{x}_{2} \cdot \mathrm{Y}=\frac{b 1 \cdot(x 1 y+b 2 \cdot(x 2 y}{\left.\square(y]^{2}\right)}
$$

\section{HASIL PENELITIAN DAN PEMBAHASAN}

\section{Hasil Penelitian}

Pada bagian ini disajikan tentang uraian hasil-hasil penelitian yang telah dicapai meliputi : (a) Deskripsi data, (b) uji persyaratan analisis dan (c) uji hipotesis penelitian ini melibatkan tiga variabel yaitu keterampilan mengajar guru sebagai variabel bebas $\left(\mathrm{X}_{1}\right)$, kedisiplinan guru sebagai variabel bebas $\left(\mathrm{X}_{2}\right)$ dan prestasi belajar siswa sebagai variabel terikat $(\mathrm{Y})$ 
Data diperoleh dari 51 siswa MTs NW Selebungtahun pelajaran 2020/2021. Masing-masing variabel dianalisis menggunakan teknik statistik sehingga dapat dengan mudah dikenali distribusi skor dan kategorinya, kemudian dilakukan uji persyaratan analisis sesuai dengan teknik analisis yang dipilih, selanjutnya barulah dilakukan pengujian hipotesis yang telah diajukan untuk lebih jelasnya akan diuraikan sebagai berikut:

\section{Deskripsi Data}

a. Data Keterampilan Mengajar Guru

Data keterampilan mengajar guru diperoleh dari hasil penyebaran angket yang terdiri dari 25 item pertanyaan. Berdasarkan data tersebut dicari Mean dan standar Deviasi Idealnya (Mi dan SDi) untuk keperluan pengkategorian dengan rumus yang telah dikemukakan pada bab ini oleh karena skor maksimal idealnya : 50 dan skor minimal idealnya 25 maka diperoleh Mean Ideal $(\mathrm{Mi})=1 / 2 \times(50+25)=37,5 \mathrm{dan}$ SDi $=1 / 6 \times(50-25)=4,16$

Dengan demikian maka konpersi yang dibuat untuk pengkategorian skor keterampilan mengajar guru

Berdasarkan hasil tabulasi skor variabel keterampilan mengajar guru dengan jumlah skor keseluruhan 2266 dengan banyak sampel atau responden 51 siswa diperoleh rata- rata skor 44,28 maka dapat digolongkan bahwa skor keterampilan mengajar guru termasuk dalam kategori baik.

\section{b. Data Kedisiplinan Guru}

Data kedisiplinan guru diperoleh dari hasil penyebaran angket yang terdiri dari 25 item pertanyaan. Berdasarkan data tersebut dicari Mean dan standar Deviasi Idealnya (Mi dan SDi) untuk keperluan pengkategorian dengan rumus yang telah dikemukakan pada bab ini oleh karena skor maksimal idealnya : 50 dan skor minimal idealnya 25 maka diperoleh Mean Ideal (Mi) $=1 / 2 x$ $(50+25)=37,5$ dan SDi $=1 / 6 \times(50-25)=4,16$

Berdasarkan hasil tabulasi skor variabel kedisiplinan guru dengan jumlah skor keseluruhan 2210 dengan banyak sampel atau responden 51 siswa 
diperoleh rata - rata skor 43,05 maka dapat digolongkan bahwa skor keterampilan mengajar guru termasuk dalam kategori baik.

c. Data Hasil Ujian Siswa

Data prestasi belajar siswa diperoleh dari hasil ulangan harian yang terdiri dari 10 item pertanyaan. Berdasarkan data tersebut dicari Mean dan standar Deviasi Idealnya (Mi dan SDi) untuk keperluan pengkategorian dengan rumus yang telah dikemukakan pada bab ini oleh karena skor maksimal idealnya : 100 dan skor minimal idealnya 10 maka diperoleh Mean Ideal (Mi) = 1/2 x (100 $+10)=55$ dan SDi $=1 / 6 \times(100-10)=15$

Dengan demikian maka konpersi yang dibuat untuk pengkategorian skor keterampilan mengajar guru

Berdasarkan hasil tabulasi skor variabel keterampilan mengajar guru dengan jumlah skor keseluruhan 3764 dengan banyak sampel atau responden 51 siswa diperoleh rata - rata skor 73,35 maka dapat digolongkan bahwa skor prestasi belajar siswa termasuk dalam kategori baik atau tinggi.

\section{Uji Persyaratan Analisis}

a. Uji Normalitas data keterampilan mengajar guru

Uji normalitas data keterampilan mengajar guru dapat dilakukan dari hasil penyebaran angket, angket tersebut terdiri dari 25 item soal dengan skor tertinggi 50 dan skor terendah 10 dengan nilai rentangan (R) 25 dengan banyak kelas 7 dan nilai panjang kelas 4. Dari hasil distribusi frekuensi untuk perolehan skor keterampilan mengajar diperoleh rata - rata atau mean 44,28 dengan simpangan baku (S) 5,71,Selanjutnya luas tiap kelas interval tersebut dikalikan dengan jumlah responden $(n=51)$ untuk memperoleh nilai frekuensi yang diharapkan (Fe) dengan hasil : 0,09;0,86 ; 3,42; 33,58; 11,70 ; -12,97 ; 5,12.

Dan diperoleh hasil $\mathrm{x}^{2}$ hitung $\leq \mathrm{x}^{2}$ tabel $(-7,66 \leq 12,592)$ artinya data berdistribusi normal.

b. Uji normalitas data kedisiplinan guru

Uji normalitas data kedisiplinan guru dapat dilakukan dari hasil penyebaran angket, angket tersebut terdiri dari 25 item soal dengan skor tertinggi 50 dan skor terendah 10 dengan nilai rentangan (R) 25 dengan banyak kelas 7 dan nilai 
panjang kelas 4. Dari hasil distribusi frekuensi untuk perolehan skor keterampilan mengajar diperoleh rata - rata atau mean 43,05 dengan simpangan baku (S) 5,82. Hasil ( $x^{2}$ hitung) tersebut kemudian dibandingkan dengan nilai ( $x^{2}$ tabel) dengan $\alpha=0,05$ dan derajat kebebasan $(\mathrm{dk})=\mathrm{k}-1=7-1=6$ yakni $\mathrm{x}^{2}$ tabel $=12,592$, berdasarkan pengujian jika $x^{2}$ hitung $\geq x^{2}$ tabel artinya distribusi data tidak normal dan jika $\mathrm{x}^{2}$ hitung $\leq \mathrm{x}^{2}$ tabel artinya data berdistribusi normal . Mengacu pada kriteria pengujian tersebut maka diperoleh hasil $\mathrm{x}^{2}$ hitung $\leq \mathrm{x}^{2}$ tabel $(-18,33 \leq 12,592)$ artinya data berdistribusi normal.

c. Uji normalitas data prestasi belajar siswa

Uji normalitas data kedisiplinan guru dapat dilakukan dari hasil ulangan harian yang terdiri dari 10 item soal dengan skor tertinggi 100 dan skor terendah 10 dengan nilai rentangan (R) 90 dengan banyak kelas 7 dan nilai panjang kelas 13 . Dari hasil distribusi frekuensi untuk perolehan skor keterampilan mengajar diperoleh rata - rata atau mean 73,35 dengan simpangan baku (S) 34 . Berdasarkan hasil penghitungan diperoleh hasil sebesar 6,94. Hasil ( $\mathrm{x}^{2}$ hitung ) tersebut kemudian dibandingkan dengan nilai ( $x^{2}$ tabel) dengan $\alpha=0,05$ dan derajat kebebasan $(\mathrm{dk})=\mathrm{k}-1=7-1=6$ yakni ${ }^{2}$ tabel $=12,592$, berdasarkan pengujian jika $\mathrm{x}^{2}$ hitung $\geq \mathrm{x}^{2}$ tabel artinya distribusi data tidak normal dan jika $\mathrm{x}^{2}$ hitung $\leq \mathrm{x}^{2}$ tabel artinya data berdistribusi normal . Mengacu pada kriteria pengujian tersebut maka diperoleh hasil $\mathrm{x}^{2}$ hitung $\leq \mathrm{x}^{2}$ tabel $(6,94 \leq 12,592)$ artinya data berdistribusi normal.

\section{PEMBAHASAN}

Keterampilan mengajar guru adalah kecakapan atau kemampuan guru dalam menyajikan materi pelajaran. Dengan demikian seorang guru harus mempunyai persiapan mengajar antara lain, guru harus menguasai bahan pelajaran, mampu memilih metode yang tepat dan penguasaan kelas yang baik.

Ada 8 keterampilan mengajar yang harus dikuasai oleh guru menurut Uzer usman (2006:74) yaitu : 1) keterampilan bertanya; 2) keterampilan memberi penguatan; 3) keterampilan memberi variasi; 4) keterampilan membuka dan menutup pelajaran; 5) 
keterampilan mengelola kelas; 6) keterampilan membimbing diskusi kelompok kecil; 7) keterampilan menjelaskan; 8) keterampilan mengajar kelompok kecil dan perseorangan

Menegakkan Disiplin merupakan hal yang sangat penting, sebab dengan kedisiplinan dapat diketahui seberapa besar peraturan dapat ditaati oleh guru, dengan kedisiplinan dalam mengajar proses belajar mengajar akan terlaksana secara efektif dan efisien.

Keberhasilan belajar siswa tidak terlepas dari keberhasilan proses belajar mengajar yang kemungkinan besar di pengaruhi oleh penguasaan keterampilan mengajar dan kedisiplinan guru, seorang guru harus mampu menguasai keterampilan mengajar dalam proses belajar mengajar agar siswa tidak merasa jenuh dan bosan diajar oleh gurunya selain itu guru disekolah dituntut menjadi seorang panutan yang baik bagi siswanya atau ia harus dapat memberikan contoh yang baik ketika mengajar sebagai cerminan bagi siswanya bagaimana berperilaku yang baik ketika mengajar, jadi ketika bertindak siswa selalu berpatokan pada sikap atau perilaku disekolah, bisa disimpulkan bahwa keterampilan mengajar dan kedisiplinan dapat memotivasi siswa untuk belajar karena siswa biasanya akan mengikuti perilaku gurunya.

Berdasarkan pengamatan yang dilakukan di MTs NW Selebung kelas VIII bahwa guru sudah menguasai keterampilan mengajar, di dalam kelas maupun diluar kelas terjadi keakraban yang baik antara guru dengan siswa, guru IPS sangat diidolakan oleh siswanya, dari hasil deskripsi data juga diperoleh bahwa keterampilan mengajar guru termasuk katagori tinggi dengan skor rata-rata 44,28. Didalam mengajar guru IPS juga sudah melaksanakan disipin dengan baik, yaitu datang tepat waktu, mentaati peraturan yang ada disekolah, dari hasil deskrpsi data diperoleh bahwa kedisiplinan guru termasuk kategori tinggi dengan skor rata-rata 43,05. Prestasi belajar siswa pada mata pelajaran IPS kelas VIII memperoleh skor rata-rata yang sama yaitu 73,35 yang berada pada kategori tinggi, ini berarti bahwa keterampilan mengajar dan kedisiplinan guru turut mempengaruhi prestasi belajar siswa, sehingga kemampuan guru dalam mengimplementasikan keterampilan mengajar dan kedisiplinan guru dalam proses belajar mengajar dituntut semaksimal mungkin guna meningkatkan prestasi belajar siswa. 
Berdasarkan analisis uji hipotesis terbukti bahwa terdapat pengaruh yang positif dan signifikans antara keterampilan mengajar dan kedisiplinan guru terhadap prestasi belajar siswa pada mata pelajaran IPS di MTs NW Selebung baik ganda maupun parsial, pengaruh parsial yang signifikans tersebut masing-masing berkontribusi sebesar $31,58 \%$ untuk keterampilan mengajar guru dan sebesar 23,43\% untuk kedisiplinan guru sedangkan pengaruh ganda yang signifikan tersebut memberikan kontribusi sebesar 27,98\% untuk keterampilan mengajar dan kedisiplinan guru. Jadi dengan menerapkan keterampilan mengajar dan kedisiplinan guru diharapkan dapat meningkatkan prestasi belajar siswa.

\section{KESIMPULAN}

Setelah dilakukan pengumpulan data maka dapat disimpulkan bahwa terdapat pengaruh yang signifikan antara keterampilan mengajar dan kedisiplinan guru terhadap prestasi belajar siswa, baik ganda maupun parsial dalam meningkatkan prestasi belajar siswa pada mata pelajaran IPS Kelas VIII di MTs NW Selebung tahun pelajaran 2020/2021. Pengaruh parsial yang signifikan tersebut masing-masing berkontribusi sebesar 31,58\% untuk keterampilan mengajar dan sebesar 23,43\% untuk kedisiplinan guru, sedangkan pengaruh ganda yang signifikan tersebut memberikan kontribusi sebesar 27,98\% untuk keterampilan mengajar dan kedisiplinan guru secara bersamasama terhadap prestasi belajar siswa.

Prestasi belajar siswa kelas VIII di MTs NW Selebung termasuk dalam kategori tinggi yaitu dengan rata-rata 73,35 dengan demikian Keterampilan mengajar dan kedisiplinan guru turut membantu meningkatkan dan menentukan tingginya suatu prestasi belajar siswa.

\section{DAFTAR PUSTAKA}

B.Uno,Hamzah.2012. Profesi Kependidikan . Jakarta : Bumi Aksara

Darmadi , Hamid. 2009. Kemampuan Dasar Mengajar Landasan Konsep dan Implementasi. Bandung : ALVABETA,CV

Depdiknas . 2007. Kamus Besar Bahasa Indonesia. Jakarta : Balai Pustaka

Hadi, Sutrisno. 2001. Statistik. Yogyakarta : Adi Of Set 
Hasan, Iqbal. 2002. Pokok-Pokok Materi Statistik I (Statistik DiskrIPStif). Jakarta : Bumi Aksara

Novi Tendra Ayu. 2008. Pengaruh Keterampilan Mengajar Dan Kedisiplinan Guru Dalam Proses Belajar Mengajar Terhadap Prestasi Belajar Mata Pelajaran Akuntansi. SkrIPSi, Universitas Negeri Semarang

Rama yulis. 2002. Ilmu Pendidikan Islam. Jakarta : Kalam Mulia

Riduwan. 2015. Belajar Mudah Penelitian untuk guru karyawan dan peneliti pemula. Jakarta: ALFABETA

Riyanto,Yatim. 2001. Metode Penelitian Pendidikan. Surabaya : Sic

Sanjaya, Wina. 2017. Strategi Pembelajaran. Jakarta : Kencana.

Santoso Sastro Poetro, R.A. 1990. Partisifasi Komunikasi presuasi dan disIPSlin dalam pembangunan. Bandung: Alumni.

Sardiman. 2007. Interaksi dan Motivasi Belajar Mengajar. Jakarta : PT. Raja grafinda Persada.

Sudjana, Nana.2002. Penelitian Hasil Proses Belajar Mengajar. Bandung : PT.Remaja Rosdakarya.

Sugiono. 2006. Penelitian Pendidikan. Bandung : Alvabeta.

Sugiono. 2013. Metode Penelitian Administrasi. Bandung: Alvabeta.

Suharsimi Arikunto. 2012. Prosedur dan Manajemen Penelitian Suatu Pendekatan Praktis.Surabaya: Usaha Nasional.

Suharsimi Arikunto.2016. Prosedur Penelitian Suatu pendidikan Praktik. Jakarta : Rineka CIPSta.

Usman, Uzer. 2006. Menjadi Guru Profesional. Bandung: PT Remaja Rosdakarya. 